\title{
Estimating long-term trends in abundance and survival for nesting flatback turtles in Kakadu National Park, Australia
}

\author{
Rachel A. Groom ${ }^{1, *}$, Anthony D. Griffiths ${ }^{1,2}$, Milani Chaloupka ${ }^{3}$ \\ ${ }^{1}$ Department of Environment and Natural Resources, PO Box 496, Palmerston, Northern Territory 0831, Australia \\ ${ }^{2}$ Research Institute for Environment and Livelihoods, Charles Darwin University, Casuarina, Northern Territory 0909, Australia \\ ${ }^{3}$ Ecological Modelling Services Pty Ltd and University of Queensland, PO Box 6150, St Lucia, Queensland 4067, Australia
}

\begin{abstract}
Flatback turtles Natator depressus are endemic to Australia and Papua New Guinea's tropical oceans and, although the species has an extensive distribution around northern Australia, there are few published long-term abundance trends of nesting populations. We conducted a longterm capture-mark-recapture program on nesting flatback turtles on Field Island in Kakadu National Park, a World Heritage Area that is jointly managed by Aboriginal landowners and the Australian Government, from 2002 to 2013 for between 12 and 20 monitoring days per year. We used a Cormack-Jolly-Seber (CJS) model that accounted for transience and recapture heterogeneity to estimate apparent survival and recapture probability, and estimated abundance using a Horvitz-Thompson type estimator. A total of 257 flatback turtles attempted nesting during that period, averaging $3.68 \pm 0.28$ (mean $\pm \mathrm{SE}$ ) nesting attempts per night of monitoring. Annual apparent survival of nesting flatback turtles was $0.97(95 \% \mathrm{CI}=0.94$ to 0.98$)$ and increased relative to body size. Recapture probability averaged $0.38(95 \% \mathrm{CI}=0.34$ to 0.42$)$ and was influenced by inter-annual climatic variability. The size of the Field Island nesting flatback turtle population ranged from $97(95 \% \mathrm{CI}=87$ to 106$)$ to $183(95 \% \mathrm{CI}=165$ to 200$)$ and there was a non-significant trend over $12 \mathrm{yr}$ of monitoring. Understanding long-term population trends of nesting marine turtles is fundamental for management and recovery of these at-risk species.
\end{abstract}

KEY WORDS: Endemic $\cdot$ Capture-mark-recapture $\cdot$ World Heritage Area $\cdot$ Recapture probability

\section{INTRODUCTION}

All marine turtle species are exposed to a range of threatening processes including fisheries bycatch, coastal development, pollution, hunting or egg collection, pathogens and climate change (Mast et al. 2005, Wallace et al. 2011). Monitoring long-term trends of marine turtles is important to inform conservation status, evaluate management decisions and track responses to management action (Campbell \& McKenzie 2004, Lovett et al. 2007). There are inherent issues with estimating abundance of marine turtles, including wide-ranging migrations, long lifespans and delayed sexual maturity, which

\footnotetext{
*Corresponding author: rachel.groom@nt.gov.au
}

inhibit direct monitoring of individuals throughout most life stages (Heppell et al. 2000, McClenachan et al. 2012).

The flatback turtle Natator depressus is the only turtle species endemic to Australia, with foraging grounds generally distributed throughout the Australian continental shelf, into Indonesian and Papua New Guinean waters (Limpus 2007, Whittock et al. 2016). It has an extensive nesting distribution from the Pilbara region of Western Australia, along the Northern Territory and Queensland coast, to central Queensland (Bustard et al. 1975, Limpus et al. 1983a, Parmenter \& Limpus 1995, Limpus 2007). In total, 5 genetic stocks of flatback turtle have been identified

() The authors 2017. Open Access under Creative Commons by Attribution Licence. Use, distribution and reproduction are unrestricted. Authors and original publication must be credited. 
(Pittard 2010), and there is evidence of restricted gene flow among some of the Arafura Sea stock, which may be more independent than genetic studies can currently determine (FitzSimmons \& Limpus 2014). Long-term (>10 yr) nesting studies on flatbacks are limited to Queensland's east coast (Limpus et al. 1983b, 1984, 2013, Parmenter \& Limpus 1995). More recently, population monitoring of nesting flatback turtles has been established at multiple rookeries in Western Australia (Pendoley et al. 2014). The species is currently listed as Data Deficient in the Northern Territory and under the IUCN (2010), and vulnerable under Commonwealth, Western Australian and Queensland legislation.

There are numerous approaches to long-term monitoring of marine turtle nesting populations. The simplest approach is the use of nesting track counts, which must be assumed to be representative if they are to apply to population abundance (Whiting et al. 2008, 2013). The most complex is multi-state open robust-design modeling using capture-mark-recapture data, which has provided highly reliable estimates of nesting female abundance, and estimated rates of recruitment, survival and breeding (Kendall \& Bjorkland 2001, Dutton et al. 2005, Rivalan et al. 2005, Troëng \& Chaloupka 2007). It is often not possible to implement the robust design due to logistic and economic limitations (Musick \& Limpus 1997, Whiting et al. 2008, Stokes et al. 2014). As a minimum requirement, abundance studies should incorporate individual heterogeneity and seasonality (Gerrodette 1993, Whiting et al. 2013).

In this study, we examine population dynamics of nesting female flatback turtles at Field Island in the Northern Territory using capture-mark-recapture data collected over $12 \mathrm{yr}$. The Field Island population belongs to the Arafura genetic stock, which extends from the Torres Strait region in far north Queensland, through the Gulf of Carpentaria, to the Northern Territory-Western Australian border. Flatback turtle rookeries are not well defined in this region, as nesting occurs throughout. However, areas of higher nesting density have been identified by Chatto \& Baker (2008) and Limpus (2007). Specifically, we describe nesting behavior, and estimate apparent survival and recapture probabilities and long-term trend in abundance of nesting females. Additionally, we examine environmental factors that influence apparent survival and recapture. The results of this study will be used to inform assessments of the conservation status of this species and prioritise resources for future monitoring.

\section{MATERIALS AND METHODS}

\section{Study area}

Field Island is located in the Van Diemen Gulf, Northern Territory, Australia, approximately $172 \mathrm{~km}$ (straight line distance) from Darwin. The unoccupied island covers 4429 ha and is $3.2 \mathrm{~km}$ from the mainland within the jurisdiction of Kakadu National Park (KNP) World Heritage Area (Fig. 1). The region experiences a monsoonal wet-dry climate, with annual average rainfall of $1571 \mathrm{~mm}$ falling predominately between November and April (Jabiru Airport, Bureau of Meteorology, www.bom.gov.au/climate/averages/ tables/cw_014198.shtml). Nesting activity by flatback turtles is limited to a small section of beach on Field Island, approximately $300 \mathrm{~m}$ on the northeast coast. An inter-tidal platform that is exposed at low tide bounds the nesting beach, obstructing the beach access for flatback turtles. 


\section{Sampling}

Annual monitoring of nesting flatback turtles at Field Island commenced in 1994. We used data from 2002 to 2013, which corresponded with more consistent survey protocols being implemented. Surveys occurred between late July and early September, as previous surveys of nesting activity on Field Island indicate that although nesting can occur throughout most of the year, this period is when most of the nesting activity occurs (Schäuble et al. 2006). Survey timing captured a full tidal cycle and corresponded with evening spring high tides (i.e. largest tidal range) to allow access to the nesting beach. Annual sampling effort measured in field days during the 3 mo sampling window varied from 12 to $20 \mathrm{~d}$. Nightly beach patrols were conducted $3 \mathrm{~h}$ either side of the high tide. Nesting turtles were measured along their curved carapace length $(\mathrm{CCL}, \mathrm{cm})$, from the anterior point at midline (nuchal scute) to the posterior tip at midline between the supracaudal scutes. All animals were individually marked with standard titanium flipper tags applied both to front right and left flippers (Limpus 1985, 1992), and a passive integrated transponder (PIT) tag implanted subcutaneously in the right shoulder. PIT tags were used to overcome problems caused by the high rates of flipper tag loss that flatback turtles typically experience (Parmenter 2003, Schäuble et al. 2006). Flatback turtles that had tag scars and no PIT tags comprised approximately $0.05 \%$ of the nesting animals. They were treated as new individuals as their capture history was unknown. Primary nesting turtles refer to turtles tagged for the first time, and tagged turtles seen in following years are referred to as remigrant turtles.

\section{Data analysis}

Survival and recapture probabilities

To estimate apparent survival and recapture rates, we used the Cormack-Jolly-Seber (CJS) model (Lebreton et al. 1992) in the program MARK v8.0 (White \& Burnham 1999). Apparent survival ( $\Phi$ ) is defined as the probability that a marked animal in the study population at occasion $i$ survives until occasion $i+1$ (i.e. between trapping occasions), while acknowledging that unobserved emigration from the trapping grid is possible (Pollock et al. 1990). Recapture $(p)$ is defined as the probability that a marked animal in the study population at occasion $i$ is captured during occasion $i+1$. Model assumptions include (1) that all animals have independent fates; (2) that every marked animal has an equal probability of recapture and survival; (3) that no tags are lost; and (4) that if temporary emigration is present, it is random (Pollock et al. 1990).

Nesting turtles exhibit 2 traits that potentially violate the assumption of equal probability of survival and recapture for the CJS model: transience and adult females skipping breeding seasons (Chaloupka \& Limpus 2001). Transients are individuals not resident in the sampling area (M2) but in transit across the area, and were captured on only 1 sampling occasion. They do not have equal survival or recapture probability to resident individuals (Cormack 1993, Pradel et al. 1997). To test these assumptions, we used goodness of fit tests in the program U-CARE (Choquet et al. 2005) using the full-time dependent model for survival and recapture probabilities. There was evidence of transience and trap-dependence (TD) in the capture-mark-recapture data for flatback turtles at Field Island (U-CARE Global TEST: transient statistic $=2.61, \mathrm{p}=0.008 ;$ trap-dependence statistic $=$ $11.44, \mathrm{p}>0.001)$. The positive trap-dependence statistic indicates that turtles exhibited 'trap-shyness', which supports the observed inter-nesting behavior of female turtles (Chaloupka \& Limpus 2002, Kendall 2004, Prince \& Chaloupka 2012, Pfaller et al. 2013). To account for these violations, we estimated apparent survival of transients separately using a timesince-marking approach (Chaloupka \& Limpus 2002). We modeled trap-dependence for recapture probability using an individual covariate to indicate if a marked turtle had nested in the previous year (Choquet et al. 2009, Limpus et al. 2013) and random effects models to account for individual heterogeneity (Gimenez \& Choquet 2010).

To examine variation in apparent survival and recapture probability, we formulated an a priori candidate set of models following the approached described in Lebreton et al. (1992). We used body size, represented by mean CCL of an individual across all years, as an individual covariate to model its effect on apparent survival of nesting flatback turtles.

To examine variation in recapture probability, we modeled the effects of 2 environmental factors that have been shown to influence recapture of marine turtles: annual rainfall and inter-annual climatic variability. The probability of a female nesting in a given year is determined by nutrition (Bjorndal 1985), environmental/climatic factors, and migration distance between foraging grounds and nesting beaches 
(Limpus \& Nicholls 2000, Solow et al. 2002, Troëng \& Chaloupka 2007). Re-migration intervals for nesting marine turtles are also influenced by environmental conditions and climate cycles affecting foraging grounds (Carr \& Carr 1970, Hays 2000, Limpus \& Nicholls 2000, Solow et al. 2002). Environmental conditions that lead to poorer quality foraging habitats can potentially lower female fecundity and subsequently decrease recruitment (Kwan 1994, Hawkes et al. 2014). We used annual rainfall ('Rain'; see Table 1) for 12 mo prior to the annual surveys from 11 weather stations on the Northern Territory coast (http://www.bom.gov.au/climate/dwo/IDCJDW0800. shtml).

Australia's climate is driven in part by the El NiñoSouthern Oscillation (ENSO), which varies the climate system on average every 4 to 7 yr. Limpus \& Nicholls (1988) observed a correlation between numbers of breeding turtles and ENSO effects, suggesting that major fluctuations in ENSO may determine the proportion of females able to acquire the fat reserves necessary for entering the vitellogenic phase of nesting preparation. Climatic variables likely to influence the nutritional pathway of turtles were not identified by Limpus \& Nicholls (1988); however, increases in net ocean primary productivity are pronounced in tropical regions where ENSO impacts on upwelling and nutrient availability are greatest (Behrenfeld et al. 2001). Similarly, large-scale inter-annual climatic variability is shown to affect reproductive frequency of marine turtles (Solow et al. 2002, Saba et al. 2007, Chaloupka et al. 2008). We used a $1 \mathrm{yr}$ average of the multivariate ENSO index (MEI), which is calculated from sea-level pressure, zonal and meridional wind, sea surface temperature, surface air temperature, and total cloudiness fraction of the sky, all observed over the tropical Pacific (Stenseth et al. 2003, Wolter \& Timlin 2011).

\section{Nesting population abundance and trend}

We used the Horvitz-Thompson type estimator (Chaloupka \& Limpus 2001, Bjorndal et al. 2005) to estimate annual abundance of nesting flatback turtles at Field Island, in which $\mathrm{N}_{i}=\left(\mathrm{n}_{i} / p_{i}\right)$, where $\mathrm{N}_{i}$ is the number of turtles in the sampling population, $\mathrm{n}_{i}$ is the number of turtles captured in the $i$ th year and $p_{i}$ is the recapture probability in the $i$ th year. Values of $p_{i}$ were derived using variance-components analysis (Gould \& Nichols 1998) in MARK v8.0 of the topranked CJS model described above to separate process and sampling error. Approximate 95\% confi- dence intervals for $\mathrm{N}_{i}$ were then derived by first calculating the standard error of $N_{i}$ as follows:

$$
\mathrm{SE}\left(\mathrm{N}_{i}\right)=\left\{\left(\mathrm{n} / p_{i}\right)^{2}\left[\operatorname{var}\left(p_{i}\right) /\left(p_{i}\right)^{2}\right]\right\}^{0.5}
$$

where $\operatorname{var}\left(p_{i}\right)$ is the variance of the recapture probability in the $i$ th year. Then, $95 \%$ confidence intervals of $\mathrm{N}_{i}$ were calculated as $\mathrm{N}_{i} \pm 1.96 \times \mathrm{SE}\left(\mathrm{N}_{i}\right)$. We evaluated trends in nesting flatback turtle abundance using variance-weighted linear regression models (Chaloupka \& Limpus 2001) in the program R (R Core Team 2012). We used a first-order moving average error to account for temporal correlation in abundance from one year to the next. The response variable was the log-transformed Horvitz-Thompson estimator for each year and an independent parameter, year, was fitted using generalized least squares (GLS) by restricted maximum likelihood estimation (RMLE).

Model selection and goodness of fit

Model selection was based on Akaike's information criterion, corrected for small sample size $\left(\mathrm{AIC}_{\mathrm{c} i}\right.$ Burnham \& Anderson 2002). The likelihood of each model, relative to others in the candidate set, was estimated with $\mathrm{AIC}_{\mathrm{c}}$ weights ( $w_{i}$ Burnham \& Anderson 2002) and models were ranked according to this measure. Finally, we performed a goodness-of-fit test on a partially saturated model (no individual covariates), using the median $\hat{c}$ procedure available in MARK (Cooch \& White 2007) to calculate a variance inflation factor $\hat{c}$. Tests were conducted using a partially saturated global CJS model because goodnessof-fit tests are not available for models containing individual covariates.

\section{RESULTS}

A total of 257 individual flatback turtles were recorded nesting on Field Island from 2002 to 2013 (Fig. 2). Of these, 160 (62\%) were re-captured at least once and primary nesting season turtles represented almost $38 \%$ of all tagged turtles at Field Island. For the $12 \mathrm{yr}$ monitoring period, the highest number of attempted nesting events by an individual turtle was 7. Approximately $7 \%$ of all turtles were observed to nest in consecutive years. During the annual surveys, there was an average of $3.68 \pm 0.28$ (mean \pm SE) nesting turtles per night (over $\mathrm{n}=220$ nights). The CCL of the nesting animals ranged from 72 to $96.50 \mathrm{~cm}$, with an average of $86.30 \pm 0.26 \mathrm{~cm}$. 


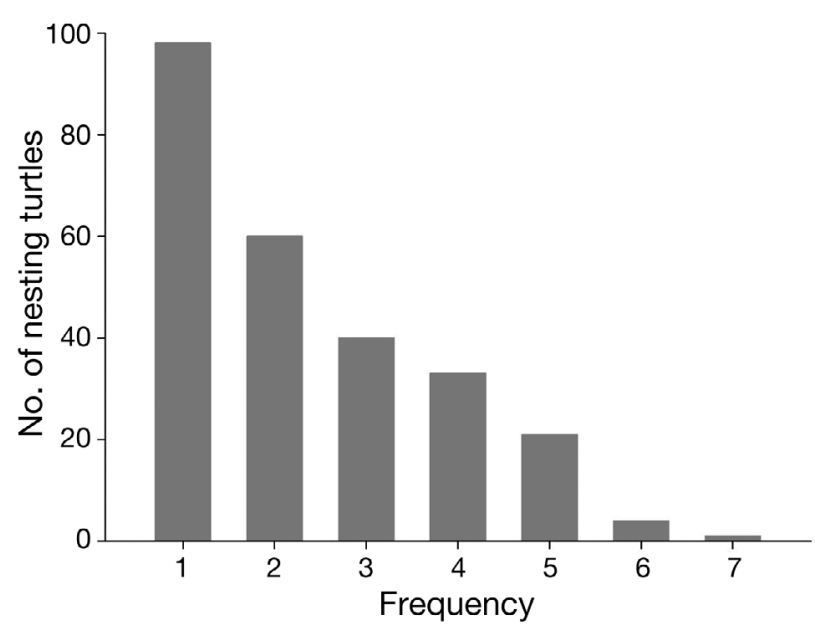

Fig. 2. Frequency of individual nesting flatback turtle encounters at Field Island, Kakadu National Park, from 2002 to 2013

\section{Apparent survival and recapture probabilities}

Apparent survival of nesting flatback turtles at Field Island was related to body size, with the top-ranked model containing the parameter CCL (Table 1). Inspection of the beta coefficients showed a significant positive relationship between CCL and apparent survival for nesting animals $(\beta=0.51,95 \%$ $\mathrm{CI}=0.16$ to 0.87$)$. For an average-sized $(86.30 \mathrm{~cm})$ nesting female at Field Island, the annual apparent survival probability was $0.97(95 \%$ CI $=0.94$ to 0.98). Recapture probability was influenced by interannual climatic variation, with models containing MEI and rainfall in the previous 12 mo ranked first

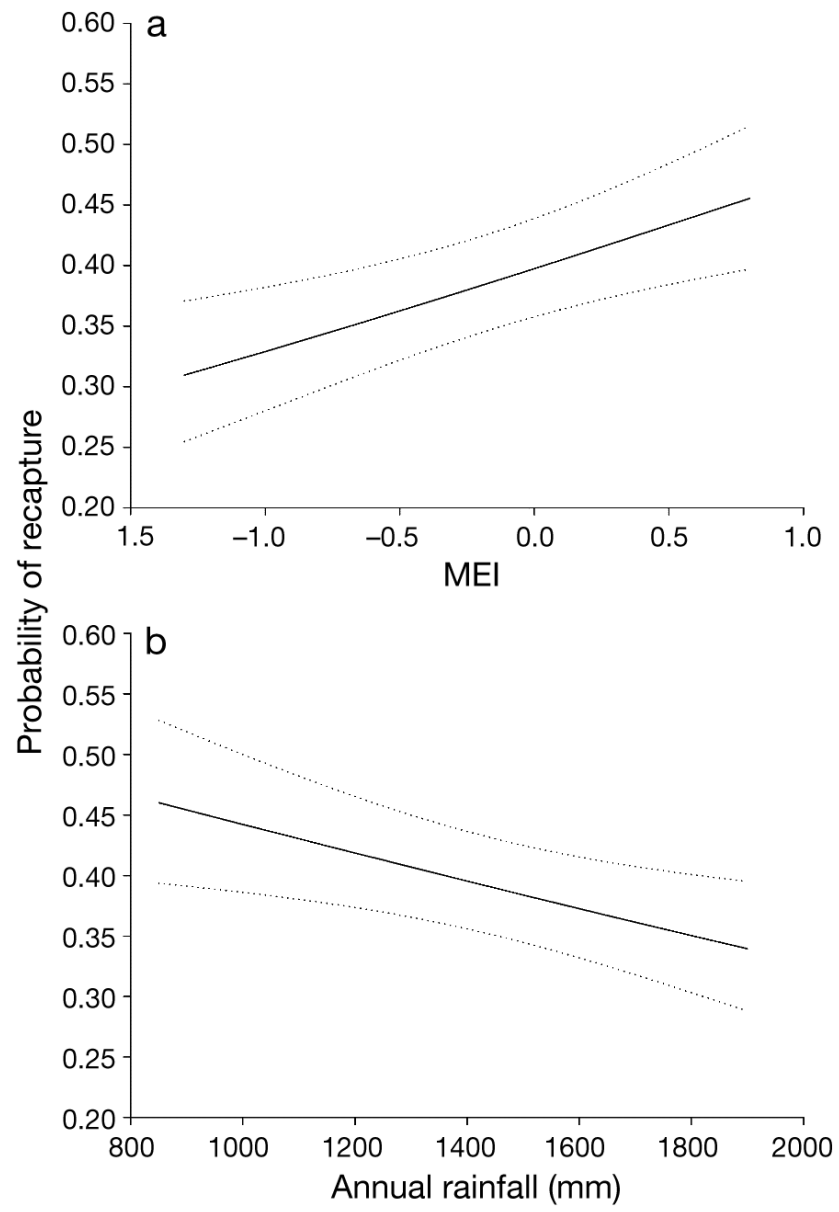

Fig. 3. Predicted relationship between recapture probability of nesting flatback turtles at Field Island and (a) the multivariate ENSO Index (MEI) and (b) annual rainfall, based on the 2 top-ranked CJS models. Dashed lines represent $95 \%$ CIs
Table 1. Summary of CJS model selection results for nesting flatback turtles, Field Island, Kakadu National Park, Australia. $K$ is the number of parameters. $\mathrm{AIC}_{\mathrm{C}}$ is Akaike's Information Criterion, corrected for small sample size. $\Delta \mathrm{AIC}_{\mathrm{c}}$ shows the difference between the model $\mathrm{AIC}_{\mathrm{c}}$ and the lowest $\mathrm{AIC}_{\mathrm{C}}$ out of the set of models. $\mathrm{AIC}_{\mathrm{c}}$ weights $\left(w_{i}\right)$ are the relative likelihood of model $i$ (normalized to sum to 1 ). ' '. refers to the null model; Time refers to the time-dependent model. The bigger the delta, the smaller the weight, and the less plausible model $i$. Model likelihood is level of support compared to the top-ranked model. See 'Materials and methods' for description of model parameters

\begin{tabular}{|c|c|c|c|c|c|}
\hline Model name & $K$ & $\mathrm{AIC}_{\mathrm{c}}$ & $\Delta \mathrm{AIC}_{\mathrm{c}}$ & $w_{i}$ & $\begin{array}{c}\text { Model } \\
\text { likelihood }\end{array}$ \\
\hline$\Phi(\mathrm{M} 2 . / \mathrm{CCL}) p(\mathrm{TD}+\mathrm{MEI})$ & 6 & 1664.11 & 0.00 & 0.56 & 1.00 \\
\hline$\Phi(\mathrm{M} 2 . / \mathrm{CCL}) p(\mathrm{TD}+$ Rain $)$ & 6 & 1665.06 & 0.95 & 0.35 & 0.62 \\
\hline$\Phi(\mathrm{M} 2 . / \mathrm{CCL}) p(\mathrm{TD})$ & 5 & 1669.66 & 5.55 & 0.03 & 0.06 \\
\hline$\Phi(\mathrm{M} 2 . / \mathrm{CCL}) p(\mathrm{TD}+\mathrm{Time})$ & 15 & 1670.16 & 6.04 & 0.03 & 0.05 \\
\hline$\Phi(\mathrm{M} 2 . /) p.(\mathrm{TD}+$ Rain $)$ & 5 & 1670.24 & 6.13 & 0.03 & 0.05 \\
\hline$\Phi(\mathrm{M} 2 . /) p.(\mathrm{TD})$ & 4 & 1674.81 & 10.69 & 0.00 & 0.00 \\
\hline$\Phi(\mathrm{M} 2 . /) p.(\mathrm{TD}+\mathrm{Time})$ & 14 & 1674.83 & 10.72 & 0.00 & 0.00 \\
\hline$\Phi$ (M2 ./.) $p$ (Time) & 12 & 1848.16 & 184.04 & 0.00 & 0.00 \\
\hline$\Phi(\mathrm{M} 2 . / \mathrm{CCL}) p$ (Time) & 14 & 1849.92 & 185.81 & 0.00 & 0.00 \\
\hline
\end{tabular}

and second within the candidate set (Table 1). Inspection of the beta coefficients showed a significant positive relationship with MEI $(\beta=0.25,95 \% \mathrm{CI}=$ 0.07 to 0.42 ) and a significant negative relationship with total rainfall over the previous $12 \mathrm{mo}(\beta=-0.17,95 \% \mathrm{CI}=$ -0.30 to -0.04 ) (Fig. 3). The mean probability of recapture was $0.38 \pm 0.02$ for nesting animals that had not nested in the previous year.

\section{Nesting population abundance and trend}

The estimated abundance of nesting flatback turtles at Field Island varied over time and ranged from $97(95 \% \mathrm{CI}=$ 


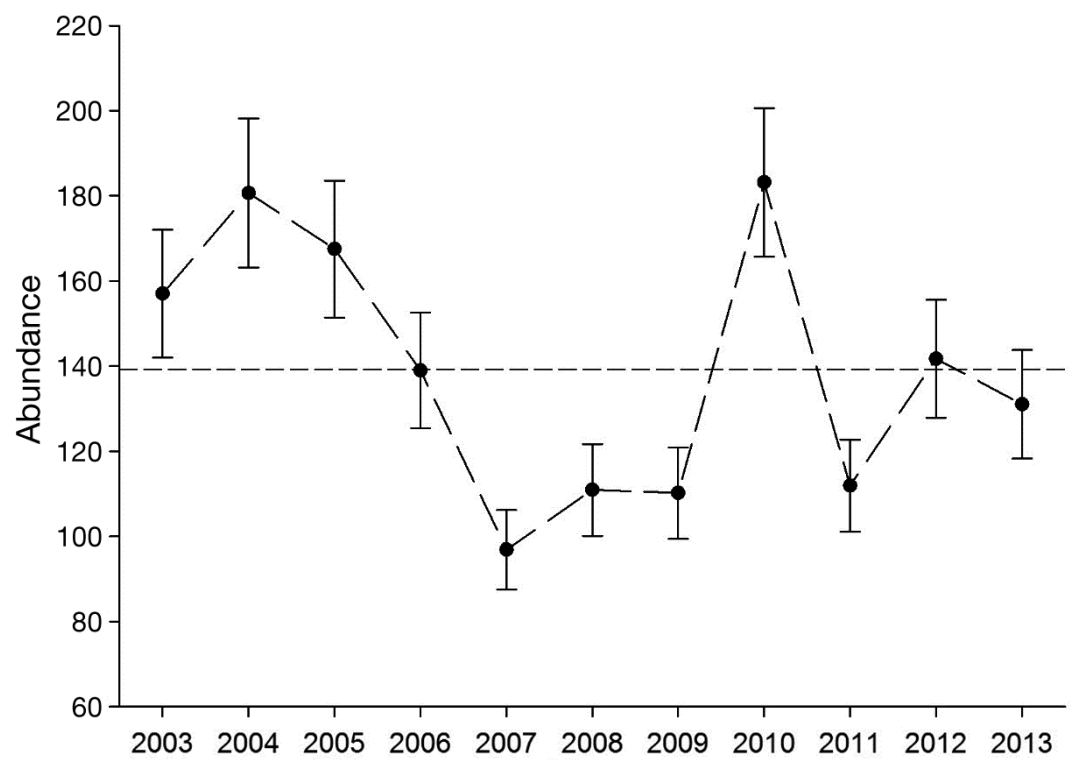

Fig. 4. Annual estimates of abundance $\left(\mathrm{N}_{i}\right)$ for nesting flatback turtles at Field Island, Kakadu National Park. Error bars represent 95\% CIs and the dashed line represents mean abundance research is required to understand the relationship between inter-annual climatic variability and flatback turtle nesting and foraging behavior, particularly in light of anticipated effects from climate change. Telemetry tagging studies on Arafura flatback turtles are limited and do not indicate areas of preferential foraging to date, but highlight the extensive use of the waters around northern Australian and neighboring jurisdictions.

Annual apparent survival probability for the Field Island flatback was high (0.97) and comparable to the stable east and west coast flatback subpopulations, which have an average of 0.94 (95\% CI = 0.91 to 0.95) (Limpus et al. 2013), and Barrow Island (Western Australia) with a predicted annual survival of 0.92 (ChevronAustralia 2015). An exception to this is the Peak Island sub-population on 87 to 106$)$ in 2007 to 183 (95\% CI = 165 to 200) in 2010 (Fig. 4). There was no significant trend detected from 2003 to 2013 for Field Island nesting flatback turtles (year slope estimate $=-0.02 \pm 0.03, t=-079$, $\mathrm{p}=0.45)$.

\section{DISCUSSION}

The results from this study show that the Field Island flatback turtle nesting population is relatively small and stable. Apparent survival was high and increased with increasing body size. Moreover, flatback turtle nesting behavior appears to respond to environmental cues, with inter-annual climatic variability influencing the recapture probability.

The recapture probability of nesting Field Island flatback turtles was influenced by inter-annual climatic variability, represented by MEI and annual rainfall in our models. Positive MEI values were correlated with higher recapture probability, suggesting that productivity at flatback foraging grounds changes in response to El Niño/La Niña events. In northern Australia, this equates to lower rainfall, higher temperatures and fewer tropical cyclones (Kuleshov et al. 2008). Most climatic effects on flatback turtles, as mid-level trophic feeders (diet primarily comprising soft-bodied invertebrates), will be indirect as these effects function through changes in ocean productivity (Doney et al. 2012, Sydeman et al. 2015). Further the east coast, which has a survival probability of 0.84 and is suspected to be declining, with no cause attributed to date (Limpus et al. 2013). The high apparent survival of the Field Island flatback turtles suggests that the nesting population is not being impacted by threatening processes that effect adult survival, such as ghost nets.

The results suggest the Field Island flatback nesting population is smaller when compared with other Australian rookeries. Annual abundance estimates ranged from 97 (95\% CI = 84 to 110) to 168 (95\% CI = 134 to 202). Although not directly comparable, nesting populations determined across a whole season at other rookeries are much larger. Barrow Island = $1986(95 \% \mathrm{CI}=1807$ to 2164$)$, Mundabullangana = 1849 (95\% CI = 1413 to 2286) (Chaloupka et al. 2012) and Peak Island = 642 (95\% CI not available) (Limpus et al. 2013). Another metric for comparison is the mean nightly nesters. For Field Island, the average number of nesting turtles per night was $3.68 \pm 0.28$ and ranged from 0 to 21 nesters per night. This is relatively low when compared with Cape Domett, with an average of 73.70 nesting turtles per night (SD = 74.80) ranging from 7 to 290 per night (Whiting et al. 2008) and Crab Island, Queensland, with a nightly nester range of 6 to 235 flatbacks (Limpus et al. 1983b, Limpus 1993). Other nesting rookeries in the Northern Territory from the Arafura flatback turtle subpopulation include West Island, Bare Sand Island and Greenhill Island, and all have similar mean nest- 
ing per night estimates to Field Island, with less than 10 turtles nesting each night over a nesting season, extending at least 9 mo of the year (Limpus et al. 1983b, Hope \& Smit 1998, Whiting \& Guinea 2003, Limpus 2007). However, northern Australian flatback nesting beaches are known to have protracted nesting seasons compared with southern beaches, which limits in their comparison (Whiting et al. 2013).

The apparently stable population at Field Island is likely subject to various threats, but these are generally unquantified in the Northern Territory. Turtle populations in Australia are vulnerable to a range of impacts such as coastal infrastructure and development, climate-related impacts, ingestion of and entanglement in marine debris, animal predation, indigenous use and habitat degradation, which are also likely to affect the Arafura flatback turtle subpopulation to varying degrees (Commonwealth of Australia 2003). Low-level mortality from ghost nets is recorded within the range of the Arafura flatback subpopulation (Mackarous \& Griffiths 2016); however, the relative significance of this mortality to other threats is unknown. The Northern Prawn Fishery (NPF) operates across the region that overlaps with habitat of the Arafura flatback turtle subpopulation. It was considered to be one of the greatest sources of flatback turtle mortality prior to the introduction of turtle exclusion devices in 2000 (Brewer et al. 2006). Riskas et al. (2016) report that flatback turtle interactions (not mortality per se) remain high, with $91.67 \%$ recorded in the NPF but little mortality recorded (NPF species interaction reports). Pelagic gillnets in the Northern Territory were also recorded to interact with flatback turtles, likely in greater numbers than indicated due to a lack of identification in this fishery (Riskas et al. 2016).

These results highlight the importance of longterm studies of marine turtles, and improve our understanding of the poorly known flatback turtle Arafura Sea genetic stock. In context with perceived threatening processes (e.g. ghost net entanglement, fisheries interactions, habitat loss, egg predation), these results will contribute to the prioritization of conservation and management actions for marine turtles in the Northern Territory, as well as the flatback conservation status assessment at a national and international level (i.e. IUCN), where it is currently listed as Data Deficient.

Acknowledgements. We thank the traditional owners of Kakadu National Park for their on-going support for the program and the numerous park staff and volunteers who collected the nesting data and assisted with program logistics.
We give special recognition to Steve Winderlich and Rod Kennett for their significant contribution toward developing and managing this study. The flatback turtle nesting study on Field Island was conducted in accord with the Kakadu National Park Management Plan and its management objectives for the flatback turtle. This plan is authorized by the Environment Protection and Biodiversity Conservation Act 1999 .

\section{LITERATURE CITED}

Behrenfeld MJ, Randerson JT, McClain CR, Feldman GC and others (2001) Biospheric primary production during an ENSO transition. Science 291:2594-2597

Bjorndal KA (1985) Nutritional ecology of sea turtles. Copeia 736-751

Bjorndal KA, Bolten AB, Chaloupka MY (2005) Evaluating trends in abundance of immature green turtles, Chelonia mydas, in the greater Caribbean. Ecol Appl 15:304-314

Brewer D, Heales D, Milton D, Dell Q, Fry G, Venables B, Jones $P$ (2006) The impact of turtle excluder devices and bycatch reduction devices on diverse tropical marine communities in Australia's northern prawn trawl fishery. Fish Res 81:176-188

Burnham KP, Anderson DR (2002) Model selection and multimodel inference: a practical information-theoretical approach, 2nd edn. Springer-Verlag, New York, NY

Bustard HR, Greenham P, Limpus CJ (1975) Nesting behaviour of loggerhead and flatback turtles in Queensland. Proc K Ned Akad Wet C 78:111-122

Campbell SJ, McKenzie LJ (2004) Flood related loss and recovery of intertidal seagrass meadows in southern Queensland, Australia. Estuar Coast Shelf Sci 60: 477-490

Carr A, Carr MH (1970) Modulated reproductive periodicity in Chelonia. Ecology 51:335-337

Chaloupka M, Limpus C (2001) Trends in the abundance of sea turtles resident in southern Great Barrier Reef waters. Biol Conserv 102:235-249

Chaloupka M, Limpus C (2002) Survival probability estimates for the endangered loggerhead sea turtle resident in the southern Great Barrier Reef waters. Mar Biol 140: 267-277

Chaloupka M, Kamezaki N, Limpus C (2008) Is climate change affecting the population dynamics of the endangered Pacific loggerhead sea turtle? J Exp Mar Biol Ecol 356:136-143

Chaloupka M, Pendoley KL, Moro D (2012) Control charts a robust approach for monitoring endangered species exposure to a major construction project. Soc Petroleum Engineers Int Conf on Health, Safety and Environment in Oil and Gas Exploration and Production 1:902-909

Chatto R, Baker B (2008) The distribution and status of marine turtle nesting in the Northern Territory. Technical Report 77/2008. Northern Territory Government Parks and Wildlife Service, Palmerston

Chevron-Australia (2015) Five-year environmental performance report (August 2010-August 2015) Document no: G1-NT-REPX0007517

Choquet R, Reboulet AM, Lebreton JD, Giminez O, Pradel LR (2005) U-CARE 2.2 user's manual (utilities-capturerecapture) version 2.2. CEFE, UMR 5175, Montpellier

Choquet R, Lebreton J, Gimenez O, Reboulet A, Pradel R (2009) U-CARE: utilities for performing goodness of fit 
tests and manipulating capture-recapture data. Ecography 32:1071-1074

Commonwealth of Australia (2003) Recovery plan for marine turtles in Australia. Environment Australia, Canberra

Cooch E, White GC (2007) Program MARK: a gentle introduction, 5th edn. www.phidot.org/software/mark/docs/ book

Cormack RM (1993) Variances of mark-recapture estimates. Biometrics 49:1188-1193

Doney SC, Ruckelshaus M, Duffy JE, Barry JP and others (2012) Climate change impacts on marine ecosystems. Annu Rev Mar Sci 4:11-37

* Dutton DL, Dutton PH, Chaloupka M, Boulon RH (2005) Increase of a Caribbean leatherback turtle Dermochelys coriacea nesting population linked to long-term nest protection. Biol Conserv 126:186-194

FitzSimmons NN, Limpus CJ (2014) Marine turtle genetic stocks of the Indo-Pacific. Ind Ocean Turtle Newsl 20: $2-18$

Gerrodette T (1993) TRENDS - software for a power analysis of linear regression. Wildl Soc Bull 21:515-516

* Gimenez O, Choquet R (2010) Individual heterogeneity in studies on marked animals using numerical integration: capture-recapture mixed models. Ecology 91:951-957

Gould WR, Nichols JD (1998) Estimation of temporal variability of survival in animal populations. Ecology 79: 2531-2538

Hawkes L, Broderick A, Godfrey M, Godley B, Witt M (2014) The impacts of climate change on marine turtle reproductive success. In: Maslo B, Lockwood L (eds) Coastal conservation. Cambridge University Press, Cambridge, p 287-310

Hays GC (2000) The implications of variable remigration intervals for the assessment of population size in marine turtles. J Theor Biol 206:221-227

Heppell SS, Caswell H, Crowder LB (2000) Life histories and elasticity patterns: perturbation analysis for species with minimal demographic data. Ecology 81:654-665

Hope R, Smit N (1998) Marine turtle monitoring in Gurig National Park and Cobourg Marine Park. In: Kennett R, Webb A, Duff G, Guinea M, Hill G (eds) Marine turtle conservation and management in Northern Australia. Centre for Indigenous Natural and Cultural Resource Management \& Centre for Tropical Wetlands Management, Northern Territory University, Darwin, p 53-62

IUCN (2010) IUCN Red List of Threatened Species. http:// dx.doi.org/10.2305/IUCN.UK.1996.RLTS.T14363A4435952 .en

Kendall WL (2004) Coping with unobservable and misclassified states in capture-recapture studies. Anim Biodivers Conserv 27:97-107

Kendall WL, Bjorkland R (2001) Using open robust design models to estimate temporary emigration from capturerecapture data. Biometrics 57:1113-1122

Kuleshov Y, Qi L, Fawcett R, Jones D (2008) On tropical cyclone activity in the Southern Hemisphere: trends and the ENSO connection. Geophys Res Lett 35:L14S08

Kwan D (1994) Fat reserves and reproduction in the green turtle, Chelonia mydas. Wildl Res 21:257-266

* Lebreton JD, Burnham KP, Clobert J, Anderson DR (1992) Modeling survival and testing biological hypotheses using marked animals: a unified approach with case studies. Ecol Monogr 62:67-118

Limpus CJ (1985) A study of the loggerhead turtle, Caretta caretta in eastern Australia. PhD dissertation, University of Queensland, Brisbane

KLimpus CJ (1992) Estimation of tag loss in marine turtle research. Wildl Res 19:457-469

Limpus CL (1993) Crab island revisited: reassessment of the world's largest flatback turtle rookery after twelve years. Mem Queensl Mus 33:277-289

Limpus CJ (2007) A biological review of Australian marine turtle species. 5. Flatback turtle, Natator depressus (Garman). Environmental Protection Agency, Queensland. www.austurtle.org.au/SeaTurtleBiology/flatback_Garman .pdf

*impus C, Nicholls N (1988) The Southern Oscillation regulates the annual numbers of green turtles (CheloniaMydas) breeding around Northern Australia. Aust Wildl Res 15:157-161

Limpus CJ, Nicholls N (2000) ENSO regulation of IndoPacific green turtle populations. In: Hammer GL, Nicholls N, Mitchell C (eds) Applications of seasonal climate forecasting in agricultural and natural ecosystems. Kluwer Academic Publishers, London, p 399-408

KLimpus CJ, Parmenter CJ, Baker V, Fleay A (1983a) The flatback turtle, Chelonia depressa, in Queensland: migration and feeding ground distribution. Aust Wildl Res 10: $557-561$

Limpus CJ, Parmenter CJ, Baker V, Fleay A (1983b) The Crab Island sea turtle rookery in the northeastern Gulf of Carpentaria. Aust Wildl Res 10:173-184

KLimpus CJ, Fleay A, Baker V (1984) The flatback turtle, Chelonia depressa, in Queensland-reproductive periodicity, philopatry and recruitment. Aust Wildl Res 11: 579-587

* Limpus CJ, Parmenter CJ, Chaloupka M (2013) Monitoring of coastal sea turtles: gap analysis. 5. Flatback turtles, Natator depressus, in the Port Curtis and Port Alma region. Report produced for the Ecosystem Research and Monitoring Program Advisory Panel as part of Gladstone Ports Corporation's Ecosystem Research and Monitoring Program. http://gpcl.com.au/EnvironmentDocuments/ EHPMonitoringofCoastalSeaTurtlesGapAnalysis5Flatback $\% 20$ turtles.pdf

炎Lovett GM, Burns DA, Driscoll CT, Jenkins JC, Mitchell MJ (2007) Who needs environmental monitoring? Front Ecol Environ 5:253-260

Mackarous K, Griffiths A (2016) Northern Territory marine megafauna strandings: July 2014 to December 2015. Northern Territory Government, Department of Land Resource Management, Palmerston

Mast R, Hutchinson B, Howgate E, Pilcher N (2005) MTSG update: IUCN/SSC Marine Turtle Specialist Group Quarterly Report: Progress from the Fifth Burning Issues Assessment Workshop. Mar Turtle Newsl 110:12-15

McClenachan L, Cooper AB, Carpenter KE, Dulvy NK (2012) Extinction risk and bottlenecks in the conservation of charismatic marine species. Conserv Lett 5:73-80

Musick JA, Limpus CJ (1997) Habitat utilization and migration in juvenile sea turtles. In: Lutz PL, Musick JA (eds) The biology of sea turtles. CRC Press, Boca Raton, FL, p 137-163

Parmenter CJ (2003) Plastic flipper tags are inadequate for long-term identification of the flatback sea turtle (Natator depressus). Wildl Res 30:519-521

* Parmenter CJ, Limpus CJ (1995) Female recruitment, reproductive longevity and inferred hatchling survivorship for the flatback turtle (Natator depressus) at a major eastern Australian rookery. Copeia 1995:474-477 
Pendoley KL, Bell CD, McCracken R, Ball KR and others (2014) Reproductive biology of the flatback turtle Natator depressus in Western Australia. Endang Species Res 23: 115-123

Pfaller JB, Bjorndal KA, Chaloupka M, Williams KL, Frick MG (2013) Accounting for imperfect detection is critical for inferring marine turtle nesting population trends. PLOS ONE 8:e62326

Pittard S (2010) Genetic population structure of the flatback turtle (Natator depressus): a nuclear and mito-chondrial DNA analysis. BSc thesis, University of Canberra

Pollock KH, Nichols JD, Brownie C, Hines JE (1990) Statistical-inference for capture-recapture experiments. Wildl Monogr 107:1-97

Pradel R, Hines JE, Lebreton JD, Nichols JD (1997) Capturerecapture survival models taking account of transients. Biometrics 53:60-72

Prince RIT, Chaloupka M (2012) Estimating demographic parameters for a critically endangered marine species with frequent reproductive omission: hawksbill turtles nesting at Varanus Island, Western Australia. Mar Biol 159:355-363

R Core Team (2012) R: a language and environment for statistical computing. R Foundation for Statistical Computing, Vienna

Riskas K, Fuentes M, Hamann M (2016) Justifying the need for collaborative management of fisheries bycatch: a lesson from marine turtles in Australia. Biol Conserv 196: 40-47

Rivalan P, Prevot-Julliard AC, Choquet R, Pradel R, Jacquemin B (2005) Trade-off between current reproductive effort and delay to next reproduction in the leatherback sea turtle. Oecologia 145:564-574

Saba VS, Santidrian-Tomillo P, Reina RD, Spotila JR, Musick JA (2007) The effect of the El Niño Southern Oscillation on the reproductive frequency of eastern Pacific leatherback turtles. J Appl Ecol 44:395-404

Schäuble C, Kennett R, Winderlich S (2006) Flatback turtle (Natator depressus) nesting at Field Island, Kakadu National Park, Northern Territory, Australia, 1990-2001. Chelonian Conserv Biol 5:188-194

Solow AR, Bjorndal KA, Bolten AB (2002) Annual variation in nesting numbers of marine turtles: the effect of sea

Editorial responsibility: Matthew Godfrey, Beaufort, North Carolina, USA surface temperature on re-migration intervals. Ecol Lett 5:742-746

Stenseth NC, Ottersen G, Hurrell JW, Mysterud A and others (2003) Review article. Studying climate effects on ecology through the use of climate indices: the North Atlantic Oscillation, El Niño Southern Oscillation and beyond. Proc R Soc B 270:2087-2096

Stokes KL, Fuller WJ, Glen F, Godley BJ, Hodgson DJ (2014) Detecting green shoots of recovery: the importance of long-term individual-based monitoring of marine turtles. Anim Conserv 17:593-602

* Sydeman WJ, Poloczanska E, Reed TE, Thompson SA (2015) Climate change and marine vertebrates. Science 350: 772-777

* Troëng S, Chaloupka M (2007) Variation in adult annual survival probability and remigration intervals of sea turtles. Mar Biol 151:1721-1730

Wallace BP, DiMatteo AD, Bolten AB, Chaloupka MY, Hutchinson BJ (2011) Global conservation priorities for marine turtles. PLOS ONE 6:e24510

*White GC, Burnham KP (1999) Program MARK: survival estimation from populations of marked animals. Bird Study 46:S120-S139

Whiting SD, Guinea ML (2006) The nesting biology of flatback turtles in the tropics: seven years of surveys on Bare Sand Island, Darwin, NT, Australia. In: Pilcher N (ed) Proc 23rd Int Symp on Sea Turtle Biology and Conservation, Kuala Lumpur, Malaysia, 17-21 March 2003

Whiting AU, Thomson A, Chaloupka M, Limpus CJ (2008) Seasonality, abundance and breeding biology of one of the largest populations of nesting flatback turtles, Cape Domett, Western Australia. Aust J Zool 56:297-303

Whiting AU, Chaloupka M, Limpus CJ (2013) Comparing sampling effort and errors in abundance estimates between short and protracted nesting seasons for sea turtles. J Exp Mar Biol Ecol 449:165-170

Whittock PA, Pendoley KL, Hamann M (2016) Flexible foraging: post-nesting flatback turtles on the Australian continental shelf. J Exp Mar Biol Ecol 477:112-119

Wolter K, Timlin MS (2011) El Niño/Southern Oscillation behaviour since 1871 as diagnosed in an extended multivariate ENSO index (MEI.ext). Int $\mathrm{J}$ Climatol 31: 1074-1087

Submitted: July 4, 2016; Accepted: November 22, 2016 Proofs received from author(s): February 7, 2017 